\title{
THE CASE STUDY OF INTERNATIONAL TRANSPORT BY THE FREIGHT FORWARDER IN FRANCE
}

\author{
Iveta Kubasáková*, Jaroslava Kubáňová, Patrícia Kollárová \\ University of Zilina, Zilina, Slovak Republic \\ *E-mail of corresponding author: iveta.kubasakova@fpedas.uniza.sk
}

Department of Road and Urban Transport, Faculty of Operation and Economics of Transport and Communications,

\section{Resume}

The article presents an analysis of the freight forwarder and carrier costs on transport in chosen country of Western Europe. Costs of transport point out to several existing problems in this part of Europe. The case study is given that deals about chosen transport in France. The article contains a review of transport routes during 2019, which were performed by an international forwarding company. These sessions were carried out in problematic areas in France. These are the transport of refrigerated and frozen perishable goods. The shipments are realized between logistics centres in France. The high problem is with carriers, with qualifications of their drivers, the number of drivers and seasonality of the goods. The article describes these problems as dependences of the forwarder's costs on individual transport routes. The article deals about more solutions, which could be used in this part of Europe.

\section{Article info}

Received 26 January 2021

Accepted 24 March 2021

Online 20 September 2021

\section{Keywords:}

forwarder,

logistics,

chain,

costs,

carrier

ISSN $1335-4205$ (print version)

ISSN 2585-7878 (online version)

\section{Introduction}

Forwarders companies are currently an integral part of the supply chain. A freight forwarder works with companies, importers and exporters, to make sure that the goods are transported in the safest, most efficient and cost-effective way. A freight forwarder works out the logistics and makes sure that all the basics are covered in the process of transporting goods from A to B. In order for the portfolio to be expanded in a targeted manner, the forwarder must also look for languageskilled employees and reduce the current employee turnover with appropriate tools. Due to the relatively strong competitive environment, it is necessary to take into account that the outgoing employee also takes the acquired contacts with him, which may in some cases deprive the employer of quality partnerships with carriers. It is important to build a strong corporate identity for employees and systematically reward their work, based on work results. It is important to note that for the most part, shipments are currently sold by people, despite an online platform where carriers can book them themselves.

As authors written in article [1], a grouping of shipments is performed to improve the logistics performance of the company. The food consignments are grouped from independent companies for one operator in order to eliminate the company's $\mathrm{CO}_{2}$ costs. The study presents a survey of dominant food flows and the models of supply chain optimization, to compare the food aggregation scenarios and their results, which can be generalized for further possible research in this area [1].

In another study, the authors described the possibilities of creating cooperating groups and how these groups should share the costs of this cooperating. They used the literature on networking, where the potential savings are modelled by cooperative play. Four business models in four different subgroups of leading companies were examined. They used a network model to determine a stable group in the calculation. The results are dependent on the selected model and it is possible to achieve different characteristics [2].

The solution is the cooperation of logistic companies, which is covered by an article with title Shipper collaboration, which solves the problem of freight transport and cooperation of individual forwarding companies in order to provide quality services at lower prices, streamlining cooperation between small and medium companies. Mathematically, Euclidean graph by a minimum costs set of constrained cycles was used. They formulated the lane covering problem, proposed several solution algorithms and conducted a computational study on the effectiveness of these methodologies [3].

The solution to the problem of transport of goods in France would also be possible by improving the quality of the rail transport, dealt with by authors in [4]. The solutions are adapted to the Spanish market, 


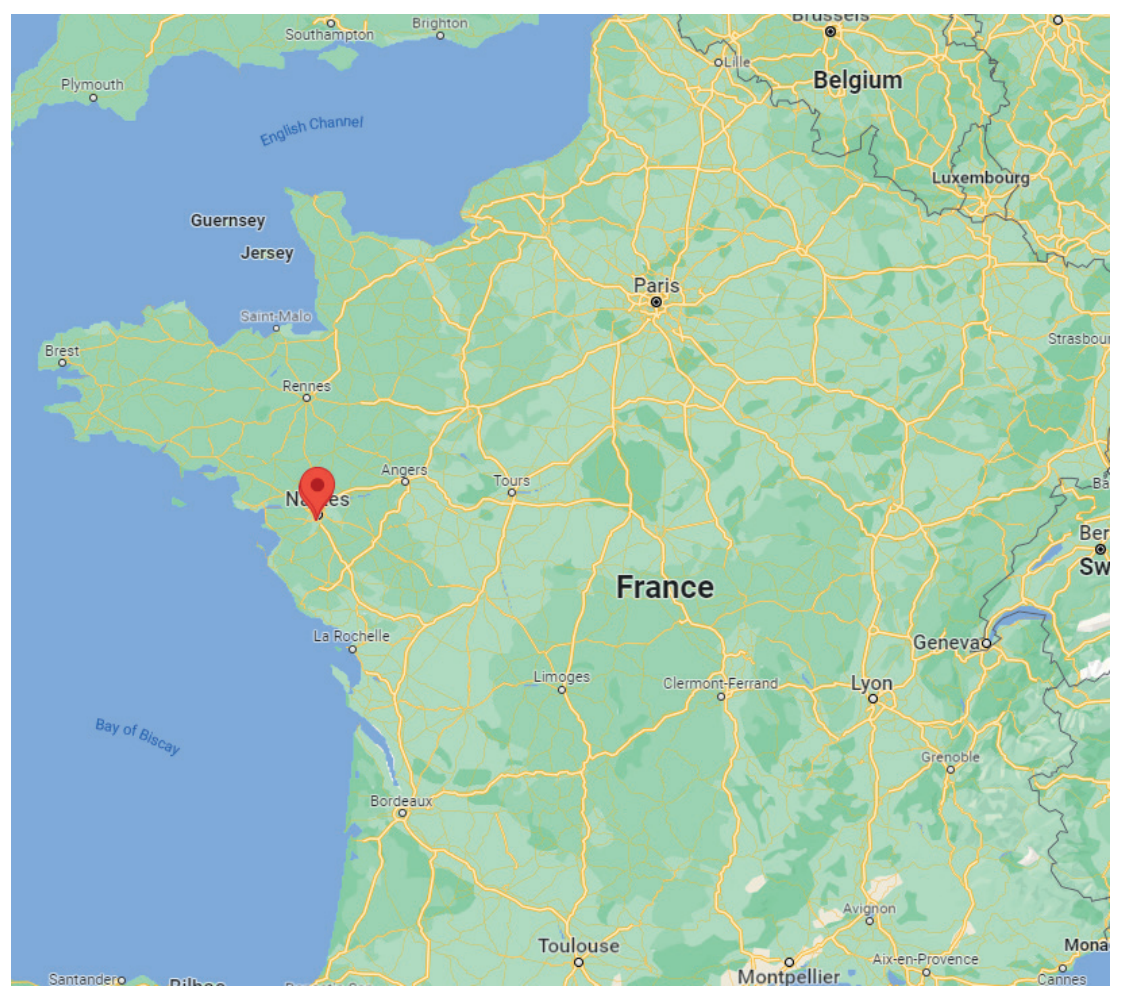

Figure 1 Location of places Dankerque and Reze on the map [GoogleMaps]

but transport services can be used on the Paris-OrleansLimoges- Toulouse (POLT) route in France, as well. Spain's competitiveness depends on such projects [4].

Very important is study [5], which is one of the first analyses demonstrating the additional environmental costs that exist between mainland France and overseas France. Thus, the results demonstrate the importance of creating a specialized and regionalized database for the case of remote islands. That database would allow for professionals to have a precise environmental assessment, not on a national but on a regional scale. This document also provides a framework and guideline for policy decision-making in the overseas islands [5].

In the article [6] is presented a model that includes the freight transport supply and demand, as well as infrastructure quality and non-time-varying fixed effects related to the route, the exporting company, its strategy and the product. The results show that distance is a determining factor in the cost of transport, in spite of the infrastructure coverage and improvements in quality. At the same time, the analysis confirms that transport costs are more sensitive to the degree of competition on the route, the volume of freight on the route and the volume of goods shipped on the route by the exporting company, the configuration of the supply chain, the company strategy and the coverage and quality of transport infrastructure [6].

Despite the size of Europe, the costs market is relatively diverse. This is mainly due to different laws that have not yet been harmonized within the European Union. Despite the decline, France had the highest share of imports within the European Union during the period 2014 - 2018. That is exactly why the France domestic transport route was chosen.

\section{The case study of chosen transport route in France}

The analysed transport route is French domestic transport. This is a temperature-controlled transport between the logistics centres in the Nord Calais region and in the Loire region. The route leads specifically, as you can be seen in Figure 1. The distance between these points was set by the freight forwarder at $635 \mathrm{~km}$. The transport was procured as one-way. The completed and validated CMR (Convention Marchandise Routière - Agreement on a contract of carriage in international road transport) consignment note required the carrier to enclose an invoice and a printed label showing the temperature in the vehicle's cargo space during the transport.

The transport routes are analyzed in this section, from several points of view. This analysis also includes the success of the shipment tracking. Based on the results of the analysis, the measures are proposed that could contribute to improving the position of the forwarding company at the market as well as to greater transparency of the supply chain.

On this route, 39 different carriers carried goods and a total of 89 shipments took place between January 2019 and August 2019. Although it was a French domestic transport, the largest representation with a share of $36 \%$ were polish carriers, followed by Lithuanian 
carriers $21 \%$ and Spanish with $15 \%$. Only one French carrier offered its services on this route.

The first transport on this route took place in January 2019. Due to the forwarder's ability to acquire carriers on this route, the number of shipments that took place increased each month. This may also be due to an increase in the customer's order, as the customer is a company, which deal with cultivation, storage and

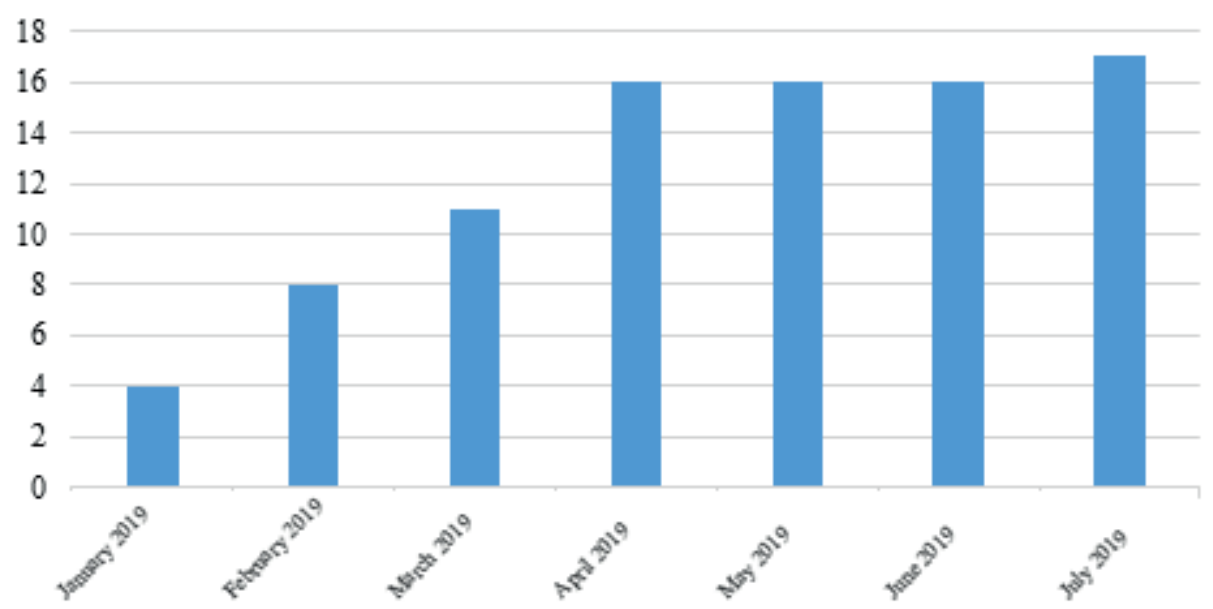

Figure 2 The number of transports per month

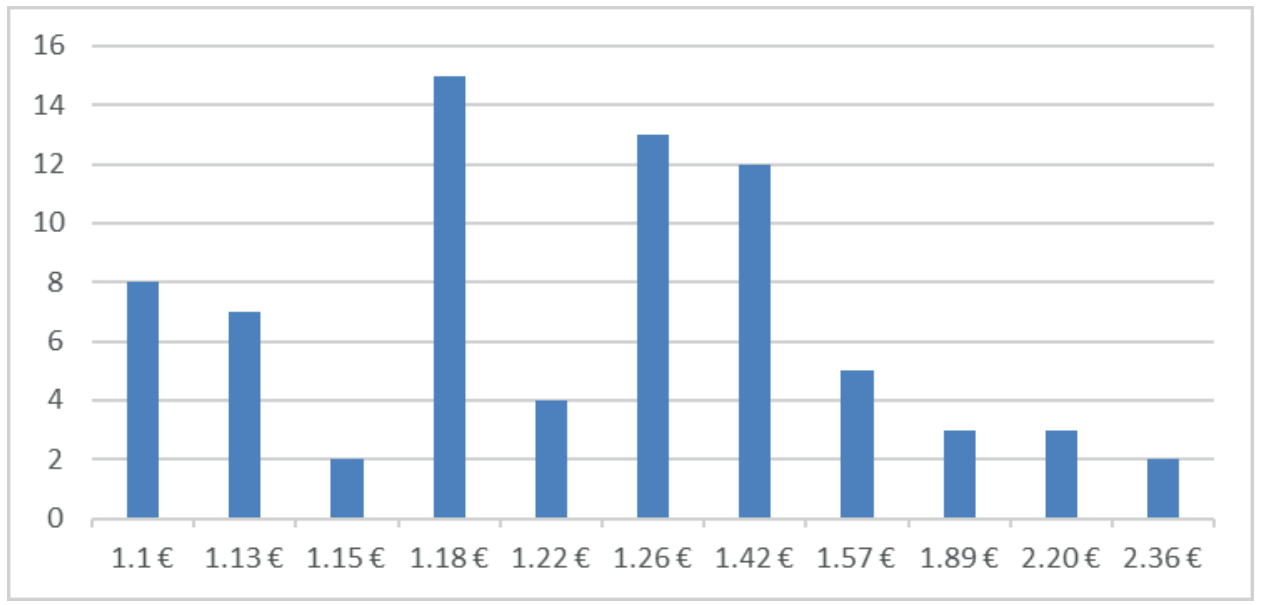

Figure 3 Absolute price rates

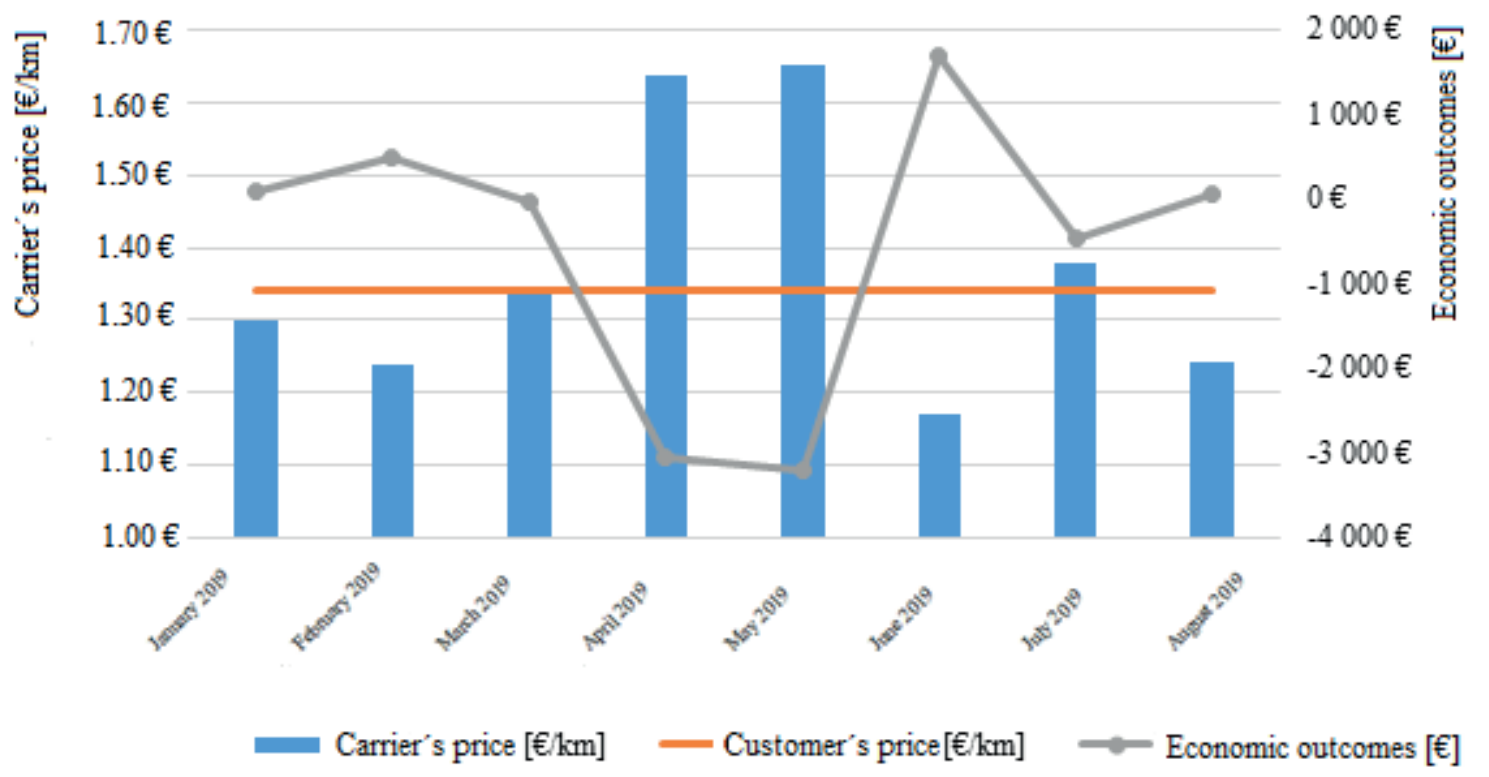

Figure 4 Seasonality of prices 


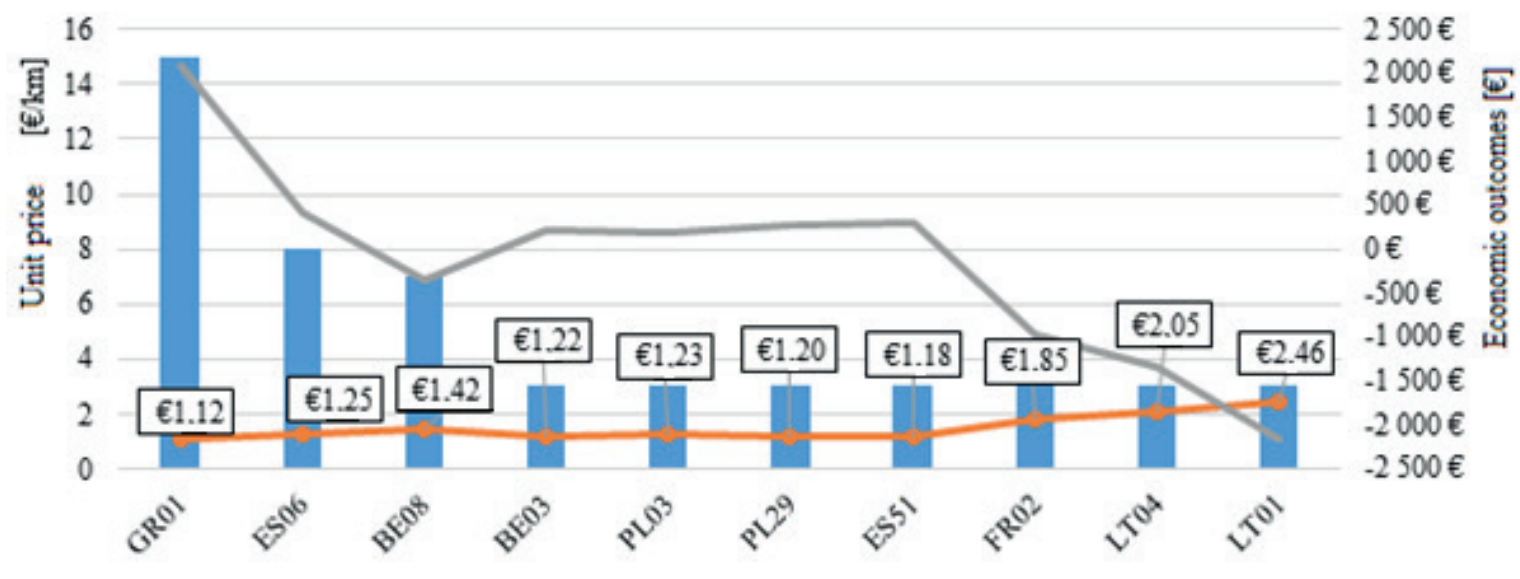

Unit price $[€ \mathrm{~km}]-$ Average price $[\ell \mathrm{km}] \longrightarrow$ Economic outcomes [€]

Figure 5 Influence of the carrier's price on the economic outcomes

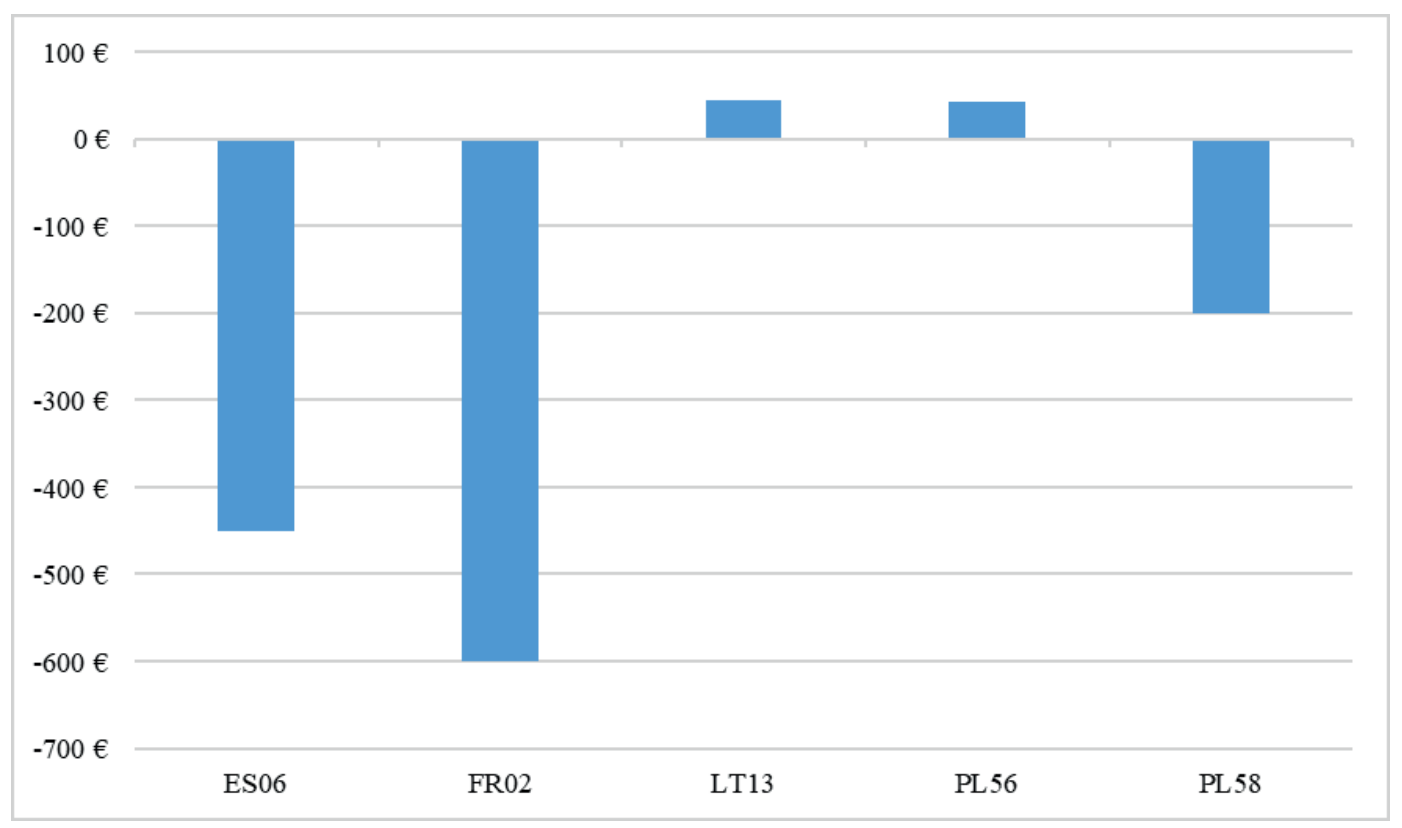

Figure 6 Paid delays and provided discounts

distribution of vegetables and fruits, for which the demand is rising in the summer months [7-9].

The data collection took place in early August, but as only one shipment was recorded in August, so this month was omitted from the statistics to avoid data distortions. The numbers of transports are presented in Figure 2.

Carriers offer the price as "ALL IN". The freight forwarder most often paid $1.18 €$ per kilometre to carriers. However, if there were low capacities on the market during the period, it was necessary to pay more than that was agreed with the customer to keep the customer. From January 2019, the price was the same, namely $1.34 €$. The following graphs (in Figures 3, 4 and 5) show how this price affected the forwarder's profit or loss and whether the carriers were able and willing to travel below this price [10].
During January, February and June, the freight forwarder was able to benefit from the carrier's prices. The largest loss was recorded during the month of May, when the forwarder had to invest $€ 3,200$ in these transports from his own financial resources. This may be due to the low capacity of refrigerated semi-trailers in the area, which is presented in Figure 3 [11-13].

Due to the cooperation with Greek carriers in June 2019, the freight forwarder was able to produce a profit, despite the fact that the demand for refrigerated semi-trailers increased with the increased temperature during the summer months. In Figure 4 can be noticed that the customer did not change his price during the whole period and that he paid to the carrier $1.34 €$ per $\mathrm{km}$. The market fluctuations reflected in prices of the carriers, therefore had to be taken over by the forwarder. 
$200 €$

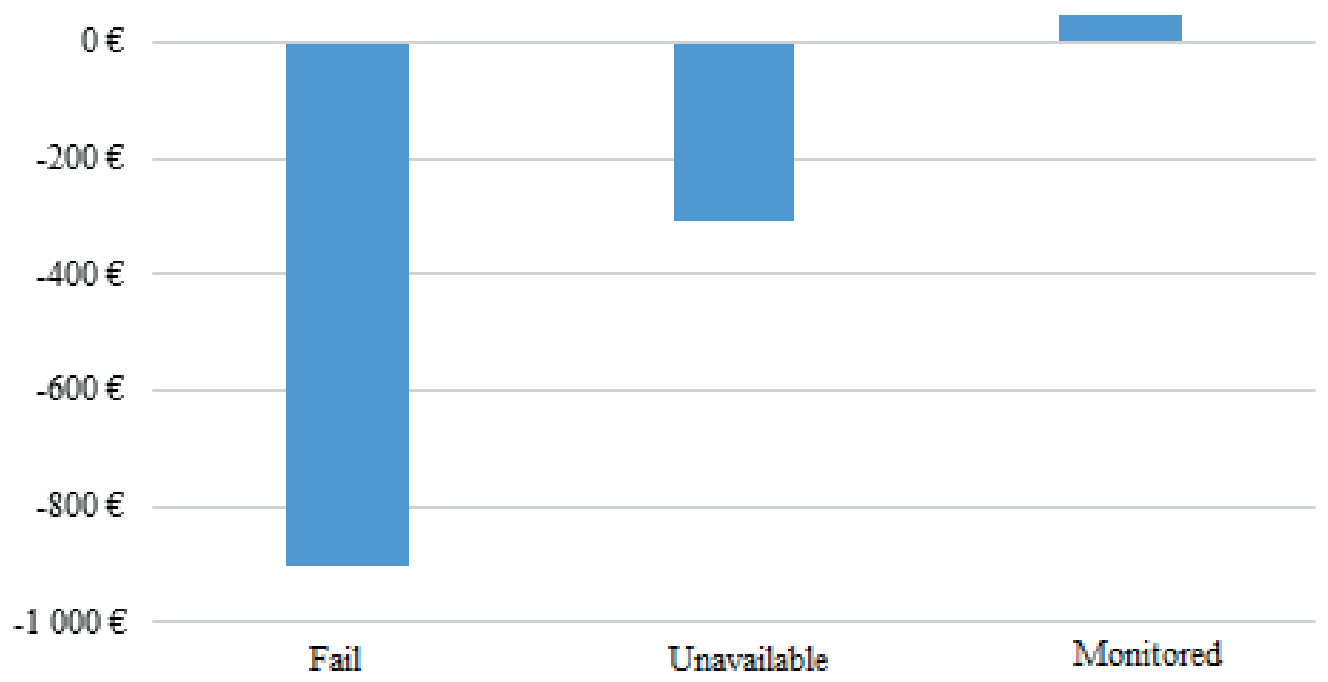

Figure 7 Relationship between paid delays / provided discounts and traceability of the shipment

The forwarder was on a loss on this route during the monitored period for EUR 4390.

The loss or profit forwarding company is caused by the unit price of the carrier. The carrier is able to reduce the unit price by increasing the coefficients of fleet utilization, journey utilization and transport capacity utilization not only on a given transport route, but within the entire company. On the route that was monitored, the lowest price was offered by a Greek carrier, namely $1.12 €$ per $\mathrm{km}$.

Among the analysed carriers, due to his optimal price and reliability he received the most shipments, namely 15 [14-15].

Figure 5 shows the effect of the carrier's unit price on the number of received shipments and the loss or profit reported by the forwarder. The loss or profit of the forwarder is expressed as the difference between the carrier's price and customer's price.

In the event that the vehicle is delayed for loading/ unloading for more than 2 hours, the customer pays for the delay, according to the pre-agreed conditions. One of them is to substantiate the movement of the vehicle from carrier's GPS or from the tracking system of the forwarder [16-17].

The delays were charged by a total of three carriers on the given route, when there was a delay in loading or unloading of more than 2 hours. For delays within 24 hours, the customer paid a delay fee of EUR 200. The delays and provided discounts are in Figure 6.

The discount was provided by 2 carriers as a result of price negotiations, or the provision or a discount to the forwarder due to the previous provision of services at a lower level than expected (e.g. late arrival of the carrier for loading/unloading).

Connection to the forwarder's tracking system can help reduce the customer delay fees paid to the carrier. It enables a faster reaction of the employee to the current situation and the movement of a vehicle and thus to be able to put pressure on the customer's logistics centre in time for loading or unloading. This saves the customers costs and the carrier's time.

The paid delays fees were paid for shipments whose status in the customer's tracking system reported either an error or unavailability. If the system reports an error, it can be cleared. Either the carrier has provided a vehicle registration number that is in the system but is not assigned to the transport or an employee in the system has assigned a vehicle registration number of the truck to the semi-trailer.

All the ten carriers, which transported the most consignments on the given route during the monitored period, also experienced errors or unavailability of tracking devices, which one can see in Figure 7.

The ten carriers were monitored, $50.98 \%$ were analysed from it. The system showed an error at $27.45 \%$ and an unavailability at $21.57 \%$. Elimination of these discrepancies should be in the interests, not only of the forwarders, but of the carriers themselves, as well, as one can see in Figure 8. The correct setting of their fleet management software predestines them to provide services at a higher level and, at the same time, provides competitiveness within the forwarder's portfolio.

Given the growing trend in the number of shipments ordered by the customer and the low number of involvement of domestic carrier, it is necessary for the freight forwarder to expand its portfolio to include carriers based in France. One of the factors that does not benefit carriers from abroad is cabotage. By Regulation (EC) no. 1072/2009 from 21 October 2009 on common rules for access to the international market for the carriage of goods by road, the carrier may transport no more than three consecutive cabotage operations within 


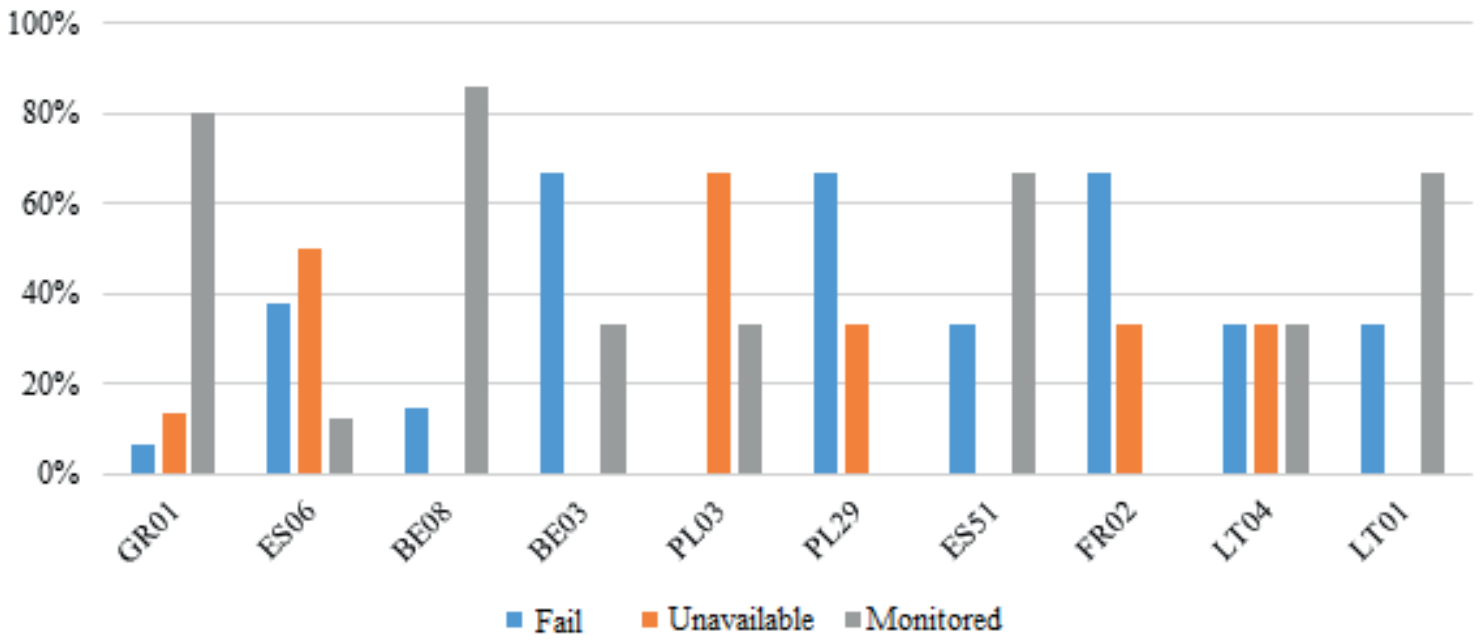

Figure 8 Traceability of the shipment

seven days from the last unloading in that member state during the importation. Insufficient knowledge of the legislation, as well as the associated sanctions, may deter carriers from doing it. In France, the fine for noncompliance with the conditions laid down, can amount to EUR 15000 The freight forwarder should not only expand its portfolio to include French carriers, but also to others that offer their services in the region. A good example could be a long-term partnership with a Greek carrier that provides his services of the high quality on this transport route [18].

One of the problems is a delay of carriers on loading or unloading, which may be a negative factor in the future, due to which carriers will either demand a higher unit price for transport or refuse this transport. During the monitored period, the customer paid a delay of EUR 1,136.60 on the Lion Plage - Reze route. In this case, it is very important to communicate with the forwarder himself, to prevent an escalation of problems, to ensure the functionality of the internal information system, as well as to recalculate the capacities of loading platforms. Minimizing the costs of delays saves resources for the customer and the carrier reduces inefficient vehicle downtime. The forwarder, who is able to promptly solve problems that occur during the transport, increases his own credibility both with carriers and customers. He gains a competitive advantage in the form of lower unit prices from carriers and more shipments from customers.

\section{Conclusions}

The analysed route served us as a suitable example of how the costs market works in Western Europe and how seasonality can affect rates. This route also explains the principle of operation of the forwarding company towards the customer and the carrier, as well as some internal procedures.

It should be of interest for the forwarder itself to expand its own portfolio. Employees need to be trained to target potential partners. The freight forwards will be upgrading its services for facility of process, increasing flexibility, transparency and availability of services. It is a necessary process for the customer's satisfaction. The company's management has access to free capacities through important transport databases, such as TimoCom, where carriers publish the location of their free capacities and, among other things, telephone or e-mail contacts. Another suitable tool for searching for the new carriers are national databases, a suitable example being the Slovak database www.jiscd.sk. Although in some cases it does not provide the contact information for carriers, it is possible to search for it in another way. The participation of the forwarder in various fairs and conferences is also important, where he can come into personal contacts with carriers.

The forwarder also offers its services for one-time shipments. If one-time transport is properly valued, it is possible to make a profit on them, as the customer needs to transport the shipment and is often willing to pay extra for this service. These shipments are appreciated by the lower management, based on previous experience or a telephone survey among carriers. A more accurate method certainly is to use a dedicated software that can plan the route correctly according to the constraints of trucks, such as length and weight. As a result, the shipper can avoid errors caused by human factors, such as incorrect valuation of the transport due to a poorly chosen distance between the place of loading and unloading. However, the quality of one-time shipments can move the forwarder to the forefront of the customer's supply chain.

The aim of article was analysis of the chosen national and international carriers on transport in Western Europe by freight forwarder. The freight forwarder provides transport in Europe. The article presents the case study of chosen transport in France. This transport is an example of existing freight forwarder as working in Europe [19-21]. 


\section{Acknowledgements}

This paper was developed under the support of project: MSVVS SR - VEGA No. 1/0245/20 Poliak, M.:
Identification of the impact of a change in transport related legislation on the competitiveness of carriers and carriage safety.

\section{References}

[1] PAN, S., BALLOT, E., FONTANE, F., HAKIMI, D. Environmental and economic issues arising from the pooling of SMEs' supply chains: case study of the food industry in western France. Flexible Services and Manufacturing Journal [online]. 2014, 26(1-2), p. 92-118. ISSN 1936-6582, eISSN 1936-6590. Available from: https://doi.org/10.1007/s10696-012-9162-3

[2] AUDY, J.-F., D’AMOURS, S., RONNQVIST, M. An empirical study on coalition formation and cost/savings allocation. International Journal od Production Economics [online]. 2012, 136(1), p. 13-27. ISSN 0925-5273. Available from: https://doi.org/10.1016/j.ijpe.2011.08.027

[3] ERGUN, O., KUYZU, G., SAVELSBERGH, M. Shipper collaboration. Computers and Operations Research [online]. 2007, 34(6), p. 1551-1560. ISSN 0305-0548. Available from: https://doi.org/10.1016/j.cor.2005.07.026

[4] DE ALARCON, R. F. Fundamental decisions for the transport of goods in Spain and with Europe / Decisiones fundamentales para el transporte de mercancias en Espana y con Europa (in Spanish). Revista de Obras Publicas. 2015, 162(3563), p. 43-50. ISSN 0034-8619, eISSN 1695-4408.

[5] AYAGAPIN, L., PRAENE, J. P. Environmental overcost of single family houses in insular context: a comparative LCA study of Reunion island and France. Sustainability [online]. 2020, 12(21), 8937. eISSN 2071-1050. Available from: https://doi.org/10.3390/su12218937

[6] CAMISON-HABA, S., CLEMENTE-ALMENDROS, J. A. A global model for the estimation of transport costs. Economic Research-Ekonomska Istrazivanja [online]. 2020, 33(1), p. 2075-2100. ISSN 1331-677X, eISSN 18489664. Available from: https://doi.org/10.1080/1331677X.2019.1584044

[7] ZAGORECKI, A., RISTVEJ, J., COMFORT, L. K., LOVECEK, T. Executive Dashboard Systems for Emergency Management. Communications - Scientific Letters of the University of Zilina [online]. 2012, 14(2), p. 82-89. ISSN 1335-4205. ISSN 1335-4205, eISSN 2585-7878. Available from: http://komunikacie.uniza.sk/index.php/ communications/article/view/751

[8] POLIAK, M., POLIAKOVA, A. Relation of social legislation in road transport on driver's work quality. In: Tools of Transport Telematics TST 2015: proceedings [online]. Vol. 531. Communications in Computer and Information Science. Cham: Springer, 2015. ISBN 978-3-319-24576-8, eISBN 978-3-319-24577-5, p. 300-310. Available from: https://doi.org/10.1007/978-3-319-24577-5_30

[9] Deloitte Intrastat guide 2018 - Deloitte [online]. Available from: https://www2.deloitte.com/be/en/pages/tax/ articles/Deloitte-Intrastat-guide-Deloitte-Belgium-Tax.html

[10] CEMPIREK, V., GASPARIK, J., ZITRICKY, V., BLAHO, P. Control of modular conveyor and automated handling devices interconnection. Advances in Science and Technology [online]. 2018, 12(3), p. 210-215. ISSN 2299-8624. Available from: https://doi.org/10.12913/22998624/94963

[11] European statistical recovery dashboard - Eurostat [online] [accessed 2020-02-17]. Available from: https://ec.europa.eu/eurostat/data/database

[12] A responsibility of the principals or user companies - Weblex [online]. Available from: https://www.weblex.fr/ weblex-actualite/transport-entreprise-etrangere

[13] Mont Blanc Tunnel: Heavy Vehicle ETC - ATMB [online]. Available from: https://www.atmb.com/en/our-offers/ mont-blanc-tunnel-cost-and-subscription/heavy-goods-vehicles-etc

[14] Royal Decree 1211/1990, of September 28, which approves the Regulation of the Law of Ordinance of Land Transport - Ministry of Transport, Tourism and Communications "BOE" [online]. Available from: https://www.boe.es/buscar/pdf/1990/BOE-A-1990-24442-consolidado.pdf

[15] HLATKA, M., STOPKA, O. STOPKOVA, M. Proposal of innovative flooring options for marine containers. Nase More [online]. 2018, 65(4), p. 174-179. ISSN 0469-6255, e-ISSN1848-6320. Available from: https://doi.org/10.17818/NM/2018/4SI.2

[16] LOVECEK, T., RISTVEJ, J. Quantitative assessment parameters of the protection level of national strategic sites in the EU [online]. In: Risk analysis VII: simulation and hazard mitigation. Vol. 43. Southampton: WIT Press - WIT Transaction on Information and Communication Technologies; 2010. ISSN 1743-3517, ISBN 9781845644727, p. PI69-PI80. Available from: https://doi.org/10.2495/RISK100071

[17] Law 16/1987, of July 30, on the Regulation of Land Transport - Head of State "BOE" [online]. Available from: https://www.boe.es/buscar/pdf/1987/BOE-A-1987-17803-consolidado.pdf 
[18] KAMPF, R., HLATKA, M., GROSS, P. Optimisation of distribution routes: a case study. Communications Scientific Letters of the University of Zilina [online]. 2021, 23(1), p. A62-A73. ISSN 1335-4205, eISSN 2585-7878. Available from: https://doi.org/10.26552/com.C.2021.1.A62-A73

[19] SIMAK, L., RISTVEJ, J. The present status of creating the security system of the Slovak Republic after entering the European Union. Journal of Homeland Security and Emergency Management [online]. 2009, 6(1), 20. ISSN 1547-7355. Available from: https://doi.org/10.2202/1547-7355.1443

[20] DVORAK, Z., REHAK, D., DAVID, A., CEKEREVAC, Z. Qualitative approach to environmental risk assessment in transport. International Journal of Environmental Research and Public Health [online]. 2020, 17(15), 5494. eISSN 1660-4601. Available from: https://doi.org/10.3390/ijerph17155494

[21] HARANTOVA, V., HAJNIK, A., KALASOVA, A. Comparison of the flow rate and speed of vehicles on a representative road section before and after the implementation of measures in connection with COVID-19. Sustainability [online]. 2020, 12(17), 7216. eISSN 2071-1050. Available from: https://doi.org/10.3390/su12177216 